\title{
From noematology to hermeneutics. Nicolae I. Apostolescu's perspective
}

\author{
Cristinel Munteanu ${ }^{\mathbb{A} \mathbb{R}^{8} 8 *}$ \\ Faculty of Communication and International Relations, "Danubius" University, Bd. Galați 3, 800654 Galați, Romania
}

\section{Article info}

History:

Received October 17, 2020

Accepted November 13, 2020

Published December 27, 2020

Key words:

noematology

hermeneutics

sense

folk etymology

text linguistics

\begin{abstract}
In this article I will analyse the contribution of Nicolae I. Apostolescu, one of B. P. Hasdeu's disciples, who (in his study, Language and its Social Manifestations) resumes his magister's discussion about noematology and enlarges its sphere, directing it to a kind of "hermeneutics of sense", appliable to both revealing the (hidden) meaning in art in general, and to etymological explanations (in order to clarify, for instance, the way in which folk etymologies appear, when the speaker makes certain connections, understands the situations which motivate certain significations in a specific way etc.). On this occasion, I will try to demonstrate that N.I. Apostolescu deserves to be considered an important forerunner of the Romanian hermeneutical research.
\end{abstract}

\section{Preliminary note}

I have dealt with the science of noematology on various occasions: once, in an article entitled Noematologia lui B. P. Hasdeu: o anticipare a skeologiei lui E. Coșeriu (based on a paper from 2013) and, a second time, more thoroughly, in my introductory study to the book B.P. Hasdeu, Studii de știința limbii [Institutul European, Iași, 2013] (see Munteanu, 2013, p. 85-94; Hasdeu, 2013, p. 58-85). Without treating the subject in detail, I had also referred to Hasdeu's noematology in relation to some Coserian ideas, in 2007 and in 2011 (see Munteanu, 2007, p. 40; 2011 a, p. 32 and 2012a, p. 356). The information I have recently ${ }^{1}$ found makes me resume the subject, especially since it confirms some suppositions for whose verification Hasdeu's text lacked the necessary proof. I refer to the contribution of Nicolae I. Apostolescu, one of Hasdeu's disciples, who, at least as regards noematology, succeeded in surpassing his master, going-as it should - with Hasdeu beyond Hasdeu.

For a start, I will explain again what noematology is. In a short and very dense study-Un nou punct de vedere asupra ramificatiunilor gramaticei comparative (published in the first issue from 1882 of the journal "Columna lui Traian") -B.P. Hasdeu proposed among the subjects of glottics (or of comparative grammar) the science of noematology as well: "a separate doctrine for what Bréal had so appropriately named «latent ideas»; o doctrine which we will name, in the absence of another term, noematology, from vón $\mu \alpha$ «intentional thought»" (Hasdeu, 2013, p. 131). At the same time, Hasdeu would emphasize the importance of the respective discipline and discussed about it in a laudatory manner ("this highly important doctrine of sub-understanding").

As a scientific term (belonging to linguistics), the neologism noematology must have been coined and used for the first time by Hasdeu. Otherwise, the oldest recording of the respective word seems to be found in Arthur Benoni Evans, the British writer's book Fungusiana or the Opinions and Table Talk of Barnaby

${ }^{\star}$ Email address: munteanucristinel@yahoo.com.

${ }^{1}$ Mention must be made that this text (in its Romanian version) reproduces in a revised form, with some essential additions, the article Din nou despre noematologie: contribuția lui Nicolae I. Apostolescu, published in "Limba română" (Chișinău), year XXIV, iss. 5, 2014, p. 78-93. 
Fungus (from 1809), but, in this case, noematology has a vague meaning, designating only the thoughts and opinions of the main character. Nowadays, the term noematology has come to be used especially in the exegesis concerning Husserl's phenomenology (see Rother, 2005, p. 205-310). About further meanings and uses of this term in the field of linguistics I discussed in a study devoted to terminological homonymy (see Moroianu \& Munteanu, 2016, p. 211-213).

\section{Formulating a hypothesis}

Referring back to Nicolae I. Apostolescu, I must mention my previous suppositions about Hasdeu's theory whose confirmation I found only at his disciple. For this, I ask for the readers' permission to reproduce a long quotation from the final part of the article in which I compared Hasdeu's noematology to Coseriu's skeology:

Obviously, the meaning which lacks expression, which we have referred to so far, might make us [...] wonder whether the respective meaning comprises the 'sense' in Coseriu's terms as well, seen as content of a text / discourse, concrete speech act etc. (see Munteanu, 2007, p. 40 and mainly 2012a, p. 356), that is the sense considered as the object of hermeneutics which Coseriu called (starting with the 50's) lingüistica del texto. It seems it does not (or at least only partially). None of the things stated by Hasdeu (and Bréal) entitles us to support such a hypothesis. At Coseriu, on the other hand, the objects of text linguistics and of linguistic skeology are clearly delimitated. This does not mean that the two «objects» exclude each other. On the contrary. In the complex reality of speech, the sense (of a literary text, for instance) cannot be born or revealed without the aid of the knowledge of 'things' (and of opinions / ideas about 'things'). As Coseriu teaches us, in a discourse / text the sense appears (or is understood) because of the combination of significations (signifiés) of language (as langue) with designation. In other words (given the fact that language [as langage] constitutes itself as a double semiotic layer), to talk, in this case, of a meaning lacking expression (i.e., signifiant) would not be entirely correct, because the significations (signifiés) convert themselves, at a superior level, in the "signifiant" associated with the sense. On the other hand, the meaning lacking expression / form which Hasdeu referred to represents the knowledge of 'things' and that is the exact object of Coseriu's skeology. (Munteanu, 2013, p. 92-93)

As observed, I was somehow puzzled by the fact that Hasdeu (perhaps, because of his desire to be loyal to Bréal's conception) had not mentioned literature as a place of manifestation of "hidden meanings", considering the fact that he himself was a writer. As a matter of fact, when I first read Hasdeu's study, I thought it was simply about that linguistic content which Coseriu (in his tripartite distinction, designation - signification - sense) had named sense (see Munteanu, 2007, p. 40 and 2012a, p. 356). Even the term noematology seemed pretty vague or susceptible of being used with another meaning, as well:

In conclusion, a few words about the two terms: noematology and skeology. It is difficult to decide which is the most suitable. Still, I have remarked that the term introduced by Hasdeu can mislead "beginners", on the one hand, because the Old Greek noéma referred, in the past, to a figure of sense (and, thus, sends us back to text linguistics); on the other hand, because in Romanian there is already the word noimă 'sense' ( $<$ Neo-Gr. nóima, derived from the O.Gr. nóema), whose meaning reminds us of hermeneutics / text linguistics, as well. (Munteanu, 2013, p. 93)

My own discovery of a study written by N. I. Apostolescu occasioned me a real feeling of satisfaction, since it demonstrated that the way in which I had understood, on my first reading, those stated by Hasdeu, could have been approved by Hasdeu himself. Before starting to demonstrate the formulated hypothesis, I think it is worth finding more about Nicolae I. Apostolescu and about his relationship with his magister. 


\section{Hasdeu's last disciple: Nicolae I. Apostolescu}

Nicolae I. Apostolescu (1876-1918) is nowadays an almost forgotten personality of the Romanian culture. Born in Alexandria, he moves to Bucharest with his family (in 1891), where he pursues his high school studies, attends the courses of the Faculty of Letters and Philosophy, obtaining (in 1899) his degree in philological sciences (magna cum laude). In university he had B. P. Hasdeu, Titu Maiorescu, Gr. Tocilescu, Ion Bianu and others as his professors. On the $9^{\text {th }}$ of February 1899, he is appointed secondary teacher at "I. C. Brătianu" High School in Pitești, where he will stay for the rest of his life. In 1905, after participating in a competition initiated by The Ministry of Public Instruction, he wins (from the "Iosif Niculescu" funds) a scholarship in Paris, in order to attend courses in semantics and comparative literature $^{2}$. Supervised by Émile Faguet, he receives his doctor's degree in philology in 1909, at the Parisian university, with two dissertations (published in France in the same year): L'Influence des romantiques français sur la poésie roumaine and L'Ancienne versification roumaine. He is one of the first comparatists of the Romanian literature and is acknowledged as one of our best specialists in versification matters. Even if he was entitled, due to his multifaceted activity and competence, to receive a university chair (in the field of the history of the Romanian literature and of literary aesthetics), he only obtained it in 1918, at the University of Iași, shortly before dying, unexpectedly, because of a pleurisy ${ }^{3}$. His personality and work were revived thanks to the efforts of Ion M. Dinu who, in 1983, published both a monography on Apostolescu and an anthology comprising some of the latter's studies and articles (see Dinu, 1983 and Apostolescu, 1983).

The relation between Hasdeu and Apostolescu was a special one for both of them. In a letter from 1904, the Professor would declare the following:

Out of hundreds of students, during about three decades of my university career, you, Mister Apostolescu, are the newest and, also, the humblest and, at the same time, the best of all, and less passionate than your magister, for I confess that I myself have always been too passionate, but I do not know whether passion—a disinterested passion-is a vice or a virtue. Almost at the end of my earthly life, I am glad that, as regards my whole literary and scientific activity, I name you my only direct legatee: nobody has understood me better, more completed and controlled. (apud Dinu, 1983, p. 38) ${ }^{4}$

After Hasdeu's death, Apostolescu made the latter a faithful literary portrait (Hasdeu, in Apostolescu, 1983, p. 180-193; see also chapter VIII, Les Hasdeu, in Apostolescu, 1909, p. 331-397). However, I suppose that the strong influence which the magister exerted on his disciple can be best deduced from a paragraph found in a portrait devoted to... Delavrancea. In 1905, while travelling in a carriage from the Câmpina station to the "castle" in which Hasdeu was living his last years, Apostolescu is surprised to observe that, in those very moments, some reflections on Barbu Ștefănescu-Delavrancea came to his mind:

The reading and re-reading of Hasdeu's works convinced me-and even more and more each day—that this man was "someone" you should have approached with an almost religious respect,

\footnotetext{
${ }^{2}$ Ion M. Dinu, the best connoisseur of Apostolescu's life and work, mentions that it is about courses in "Semantics, Noematology [sic!] and comparative literature" (see Dinu, 1983, p. 5), but he does not say where he took this information from. Otherwise (see, for instance, Faifer, 2004, p. 206 and even I.M. Dinu, in his preface to Apostolescu, 1983, p. 6), only courses in semantics and comparative literature are referred to. There were indeed no courses in noematology in Paris; therefore, it must have been Hasdeu's or someone else's recommendation, who knew since 1900 that Apostolescu had discussed about noematology.

${ }^{3}$ For further details about N. I. Apostolescu’s life and work, see, mostly, Dinu, 1983.

${ }^{4}$ The letter is from August $9^{\text {th }} 1904$ (also cf. I. M. Dinu's preface to Apostolescu, 1983, p. 9). Nicolae I. Apostolescu would reproduce it in the "foreword" to his volume of studies from 1904, together with the recommendations made by Gr. Tocilescu and G. Ionescu Gion.
} 
and I do not hesitate to say it: whenever I had the chance to talk to him, to spend a few hours or a few days in his company, or even when I only saw him, I would feel a deep and supreme emotion. So, you could imagine the surprise, the amazement which I felt during the minutes when my whole mind was charmed by Hasdeu's great personality, to find room for another writer, or even to reflect for a few minutes - as it happened to me-on the beauty of the expressions from Mr. Delavrancea's works. (Delavrancea, in Apostolescu, 1983, p. 283)

\section{Language and its social manifestations}

After these more or less introductory remarks, but still necessary, we can now examine at length our author's contribution.

The study Limbajulși înfạțişările lui sociale [Language and Its Social Manifestations] (also re-published in Apostolescu, 1983, p. 86-144) was initially a conference entitled Despre cuvint [On Word] (delivered on the $14^{\text {th }}$ of May 1900, at "Societatea istorică a studenților în litere"), being printed (with this title) both in the journal "Tinerimea română" (new series, vol. IV, fasc. 1-2) ${ }^{5}$, and as an excerpt (in a brochure ${ }^{6}$ ) in the same year. Apostolescu will include it (with minor additions) in an anthology of his own works, Studii. Literatură, estetică, filologie (Institutul de arte grafice "Eminescu", București, 1904, p. 99-137) Language and Its Social Manifestations contains the following sections: Origin of language according to various thinkers; Speech and art; Latent ideas - noematology; Semasiology and noematology; Phonetic alteration; Proper names; The law of memory regression - the derivation of the parts of speech.

Judged as a whole, the material we are dealing with-apart from some notable exceptions (including the issue of noematology) - lacks originality, especially regarding the linguistic facts analyzed. This is justified, since it was first written for the students in philology from "Societatea istorică". Thus, the "study" resembles more to a university lecture in which Apostolescu, using a lot of quotations taken from authorities in the field and summarizing various conceptions, presents a series of essential aspects of the human language. The thirst of knowledge of this high school teacher must have been extraordinary, since not only did he mention the linguists' and philologists' opinions (A.H. Sayce, Max Müller, M. Bréal, A. Darmesteter, W.D. Whitney, B.P. Hasdeu, A. Lambrior, L. Șăineanu, A. Philippide, O. Densusianu etc.), but he referred to naturalists (including Ch. Darwin, of course), historians, sociologists, philosophers etc., as well. There are also references to writers (Lucretius, Anatole France, B. Șt.-Delavrancea) or specialists in aesthetics and literature (C. Martha, for instance).

From the very beginning, Apostolescu insists on the social character of language. The attention the lecturer pays, from the first pages, to the relation between language and art (in the section Speech and art) is impressive: "There is no other social manifestation more tightly connected to speech than art, which some people partially overlap or mistake one for the other" (Apostolescu, 1983, p. 91) ${ }^{8}$. The fact that the author, discussing linguistic topics, envisages permanently (due to his interests and education) the dimension of art in general and of literature in particular will prove its significance at some point of his discourse. Obviously, I do not aim at presenting here and commenting on the whole content of the aforementioned "study". Recording the main topics treated by Apostolescu is sufficient. Undoubtedly, some ideas of the linguistic sciences of those times are not acceptable nowadays, but I was not interested in emphasizing these ones. I only wanted to underline some excellent intuitions which Apostolescu had concerning the

${ }^{5}$ Ion M. Dinu (1983, p. 58) notes that it might have been published (again?) in “Tinerimea română”, vol. VI, fasc. 1-2, in the draft of Gr. Tocilescu, Istoria românilor. I could not verify if it was an addition or a sequel of the first version.

${ }^{6}$ Published at Tipografia "Corpului didactic C. Ispășescu și G. Brătănescu”, București, 1900 [36 pages in total].

${ }^{7}$ For this volume, Nicolae I. Apostolescu was also awarded "The Adamachi Prize” (of 500 lei) of the Romanian Academy for the year 1904 (see Bianu, 1905, p. 319). In his favourable report, N. Quintescu considered the study Limbajul și înfățişările lui sociale as "the most important, scientifically speaking" of his entire book (Quintescu, 1905, p. 423).

${ }^{8}$ Indeed, it is sufficient to read Benedetto Croce's Asthetic (published in 1902), to find out that such an opinion was quite common in that epoch. 
subject-matter of noematology. That is why I will mainly analyze in what follows the pages from the two sections devoted to this science: Latent ideas - noematology and Semasiology and noematology. Even so, one must mention that the two sections represent almost a third of the paper. One could also add some paragraphs (Apostolescu, 1983, p. 119, 123 and 127) from the section Phonetic alteration, in which Apostolescu explains certain semantic changes by means of latent meanings, as well.

\section{With Hasdeu beyond Hasdeu}

What is, actually, N.I. Apostolescu's contribution? How does he surpass Hasdeu in the field of noematology? I would say that Apostolescu has at least two merits in this regard: (1) the fact that he linked the problem of hidden meaning, as formulated by Hasdeu, to art as well (or to literature, mostly); (2) the fact that he used noematology and the notion of 'latent idea' explicitly in discussions concerning etymologies. Apart from these, Apostolescu made some remarks about the level of 'sense' whose importance I will underline later.

Let us remember that, preparing his proposal concerning the doctrine of noematology, Hasdeu states the following: "Speech is a means of mutual understanding. Mutual understanding is achieved not only through the expressed meaning, which constitutes the subject-matter of semasiology, but also, even more, through a hidden meaning, devoid of expression, an implied one, which manifests itself mostly in syntax" (Hasdeu, 2013, p. 130). The unexpressed meaning, on which Hasdeu insists, is-as he states it right away- "the latent idea" theorized by Bréal. Apostolescu knows these things very well, since he quotes from (and cites) both studies: Hasdeu's from 1882 (on the divisions of comparative grammar) and Bréal's, Les idées latentes du langage (based on a conference delivered in 1868) ${ }^{9}$. Moreover, unlike Hasdeu, Apostolescu also offers some Romanian examples (apart from some French examples taken from Bréal) "in order to better clarify the importance of this doctrine of noematology": "But in Romanian the suffix $-i e$ has the same value in pescărie [fishmonger's] from pescar [fisherman] and in olărie [pottery] from olar [potter]? In this case only the latent ideas can explain the role of these suffixes. We must have, according to Bréal, the ability to sub-understand some relations of a concrete nature and of a particular species which our mind guesses more than perceives in the expressed words" (Apostolescu, 1983, p. 103). As I already indicated (see Munteanu, 2013), 'the latent ideas' are also the subject-matter of the skeology theorized by Coseriu. But not everything that belongs to Hasdeu's noematology, as redesigned by Apostolescu, belongs to Coseriu's skeology. A part of noematology—as Apostolescu sees it-rather belongs to hermeneutics. How can we prove such an assertion? I will try to give an answer in what follows.

In the section entitled precisely Latent ideas - noematology, before treating Bréal's latent ideas and Hasdeu's noematology, Apostolescu starts from art in general, not from language. An artist should offerfrom the very beginning - the listener, the beholder and the reader the possibility ("to let gates open and make bridges [for them]") to discover, "through associations of ideas, the hidden meanings": "There is a certain discretion which every art should possess and a certain substratum, a hidden meaning which every word should have" (Apostolescu, 1983, p. 101). Next, he presents some ideas and examples taken mostly from Constant Martha's book, La délicatesse dans l'art (1884, the $1^{\text {st }}$ edition), from the chapter La discrétion dans l'art et les sous-entendus (Apostolescu, 1983, p. 101-102). Martha records various cases (from painting, literature, music, but also from everyday life) in which the force of suggestion acts, in which, thanks to some associations of ideas, hidden meanings are revealed to us: a terrified face, a withered flower, the sound of a bell, the smell of the freshly mown hay or of a perfume etc. can cause real illumination in the consciousness of those who experiment them through their senses. At the level of discourse ("in speech”), metaphor, symbol, allegory, hyperbole, irony etc. also generate hidden meanings (Apostolescu, 1983, p. 102).

Summarizing some paragraphs from C. Martha's book (to which he makes exact references in footnotes), Apostolescu gives the impression, at first sight, that he translates word for word from French. How-

\footnotetext{
${ }^{9}$ For an analysis of M. Bréal’s (1868/1882) work, see my introductory study to Hasdeu, 2013, p. 70-74.
} 
ever... I reproduce, in parallel, two quotes (one from Martha's original and the other from Apostolescu's synthesis):

( $\alpha$ ) “L'art d'écrire n'est le plus souvent que l'art de suggérer d'idées et de sentiments qu'on n'en exprime. [...] Tantôt par une image, tantôt par un seul mot ils nous découvrent un monde" (Martha, 1907, p. 115$)^{10}$.

( $\beta$ ) "The art of writing and the art of speaking, as well, are not, most of the times, but the art of suggesting ideas and feelings, unexpressed, but implied [my emphasis, C.M.]. Often, only through a word or an image, a whole world is revealed" (Apostolescu, 1983, p. 102).

It can be easily observed that Apostolescu (in "translation" / summary) added, on his own, the words "the art of speaking" and "but implied", not only to complete Martha's words, but also to prepare the discussion concerning the latent ideas and noematology, an intention that can also be seen in the inversion he made, meant to change the focus from image to word (let us compare the phrase "only through a word or an image" to the Fr. original "tantôt par une image, tantôt par un seul mot"). Indeed, immediately after that, Apostolescu resorts to Bréal and to Hasdeu and the discussion turns into a mainly linguistic one, even if the parallel art - language is still maintained: "Just as in art, in language, these latent ideas, implied, are a necessary condition for the progress of human thinking" (Apostolescu, 1983, p. 102-103) ${ }^{11}$.

Thus, Apostolescu subtly (as we will see later) enlarges the sphere of noematology, also including among the latent ideas (or meanings) the senses of artistic works (mainly of literary works). A specialist in Hasdeu's work and passionate about literature, it would have been impossible for him not to connect, appropriately, the "hidden, devoid of expression, implied" meaning (see supra) to the sense of the work of art, especially since he considered (unlike some current theories) that art, just as language, is a social phenomenon. In fact, a few pages before, in the section Speech and art, the author would state his objectives:

If speech is social, art as such is even more social [...]. Researching in parallel some manifestations of art and speech, one will understand better this resemblance between the two psychical phenomena in their process of creation and expression. The ability or inability of an artist or of a common speaker to express everything that he feels, or wants-is the core around which the elements of this discussion will gravitate. (Apostolescu, 1983, p. 93; also cf. p. 98-100)

Placing the analysis on the field of language, Apostolescu chooses "one of the most beautiful examples of evolution of a word thanks to the latent meanings". He refers to the way in which multumesc 'thank you', coming from the greeting "la mulți ani", got its present meaning (after changing its phonetic form, apparently, also under the influence of mulțime 'crowd'):

The transfer from one meaning to another was possible due to its hidden meaning. When greeting someone with “să trăiești mulți ani” ['may you live long'], in time, people thought that it was a thank you phrase, an answer to a greeting; they only thought of the hidden meaning, not of the expressed one. After some time, the latent meaning replaced the expressed one-possibly at the same time with the phonetic change, which resulted in the blending of the two words in one. (Apostolescu, 1983, p. 104) $)^{12}$

\footnotetext{
${ }^{10}$ The further editions of C. Martha's book are, actually, republished versions of the first edition from 1884 . I read the fourth edition, from 1907. Apostolescu refers, in his study, to an edition from 1897, and then, in his doctoral thesis, he uses the very first edition (see Apostolescu, 1909, p. 4).

${ }^{11}$ Apostolescu makes reference, in a footnote, to Bréal's study. There is no reference to art neither on the indicated page, nor in the whole book of the French linguist. Similarly, C. Martha does not mention M. Bréal anywhere in his book.

${ }^{12}$ Apostolescu frequently also quotes from Șăineanu's works. In the latter's Semasiology, there is a similar example which was worth being mentioned: "Bogdaproste or bodaproste 'May God forgive your sins', a way of thanking specific to beggars, which, frequently repeated, becomes a boring chatting, hence the phrase: a umplea [sic!] pe cineva de bogdaprosti 'to fool somebody' (Șăineanu, 1999, p. 194).
} 
This example and the ones that follow in the section Semasiology and noematology adequately outline the subject-matter of noematology as linguistic skeology. As mentioned before, to Coseriu, skeology deals with the research of the contribution of the knowledge of 'things' (and of the opinions or beliefs about 'things') to speech. It is these very aspects which Apostolescu wants to highlight, reinterpreting from a noematological perspective-as I would call it-some of Hasdeu's etymological investigations, which the scholar published in "Columna lui Traian" shortly after he had treated (in the same journal) the topic of noematology. It is a surprising fact that in the respective articles-S,ugubăts și şugubină (1882), Creștet și urzică (1882), Scornesc și stîrnesc (1883) (see Hasdeu, 1988, II)-Hasdeu does not use, at least once, the concepts (or the terms) 'latent idea' or 'noematology' ${ }^{13}$. Thus, Apostolescu's effort is even more praiseworthy.

Among other things, he tries to prove (mixing his own observations with Hasdeu's explanations) "the way in which the semantic and the noematological aspects" led to the current meaning of the word sugubină. I think it is instructive to see how he does it. From the Sl. sugubina, initially signifying in Old Slavic 'loss of soul', the term came into Romanian with the meaning of 'illicit sexual affair', "any illegitimate affair between a man and a woman being considered 'a loss of soul' according to the church" (Apostolescu, 1983, p. 105). Through metathesis, duşegubină > deşugubinăa, what resulted being explained through a "double folk etymology", since it was believed: "1) that we deal with two words-the first is the preposition de, and the second, sugubină; 2) that the word şugubină-specific in this form to the Romanian language only-means 'mauvaise plaisanterie', trouble, strange happening" (Apostolescu, 1983, p. 105). In order to bring the discussion into the sphere of noematology, Apostolescu rephrases Hasdeu's analysis as follows:

Duşegubina was in the old Romanian legislation a 'forbidden sexual affair', and in general people give this name to the 'crime', as it results from the texts quoted by Hasdeu in his study. The one who would commit such a forbidden act had to pay or give an indemnity. To pay dusegubina - and later deşugubina - that is to pay for the crime, the sin, as ransom, has now in the people's mind the meaning of 'to pay a fine', 'to pay for', in other words, duşegubina or deşugubina started to designate 'fine', 'indemnity'. Here comes the latent idea: to pay a fine meant 'to be in trouble'. This was the hidden idea, which, together with the expression "a da dușegubină", changed, in time, to "a da de șugubină", and with the folk etymology which associated our word to şuguesc ['to joke'], resulted in the current meaning 'mauvaise plaisanterie', trouble, bad happening. (Apostolescu, 1983, p. 105-106)

Indeed, numerous such cases of "combinations of semasiological and noematological phenomena" (as Apostolescu calls them) could be invoked. It would be sufficient to enter the field of phraseology, researching the origin of some set phrases such as a-și aprinde paie-n cap (cf. Șăineanu, 1999, p. 232-234 and Dumistrăcel, 2001, p. 294-295), a da bir cu fugiții (cf. Dumistrăcel, 2001, p. 46) and many others, in order to perceive the possible benefits which noematology, applying Apostolescu's "recipe", would bring.

Hasdeu's disciple, stimulated by his articles, Creștet și urzică and Scornesc și stîrnesc, is more interested in folk etymology, trying to determine how the mental mechanism responsible for such a transformation works:

One more thing results from the analysis of the procedure followed by the people in using their specific type of etymology: they attribute to the notion-word some nuances which the word does not possess, dissatisfied with a too vague, too unclear meaning they grasp from the start. Wanting to explain to themselves the origin and the family of the word-which they are not able to know in a scientifical way - they attribute it a certain evolution, usually taking as a point of departure a random phonetic resemblance. (Apostolescu, 1983, p. 107)

\footnotetext{
${ }^{13}$ As a matter of fact, I did not find another work in which Hasdeu later used the two notions. Regarding [the Rom.] ideologic (used in phrases such as "ciocnire ideologică" ['ideological collision'] etc.) or [the Rom.] ideologie, these are due to Schleicher's influence, meaning 'semantic' (or 'semasiological'), respectively 'semantics' (or 'semasiology').
} 


\section{Noematology and hermeneutics}

What we find next in N.I. Apostolescu's discourse is highly important, in my opinion, at least as intuition:

This tendency which the people have in order to satisfy their etymological curiosity goes from a single word to a whole literary work. Everybody looks for the signification and origin of a word: e.g., the first speaker in the various occasions he encounters when pronouncing or reading that word. But the one who is familiar with a literary culture will try-most of the time-to better grasp the sense of a line, of a poem, of a novel, of a drama, of a philosophical doctrine. (Apostolescu, 1983, p. 107-108)

Why do I believe that Apostolescu states something of great significance here? For he proves what we could call "hermeneutical attitude". He realizes the fact that "everything is interpretation". Hans-Georg Gadamer (2001, p. 714-715) might have referred, in this case, to the "universality of hermeneutics". We interpret not only texts, but also present or historical situations. And we do this by means of the expressed (externalized) language or by means of the inner discourse (cf. Munteanu, 2019, p. 38). It is not always relevant whether the result of the interpretation is true or not. In the ocean of meanings we live in, "the truths" scientifically verified are but an island (see Dewey, 1963, p. 4-5).

Among the lines dedicated to linguistics matters, according to his habit, Apostolescu inserts other reflections on literature. Discussing about the sense of a work (be it drama, poetry or philosophy), he affirms the following:

He will often consider it as a piece of canvas incompletely embroidered, and he will insert ideas of his own all over the cloth. Thus, this work will be presented to the mind of a hundred of individuals in a hundred ways, in accordance with the perspective from which each of them contemplated, completed, understood it. [...] And this is explainable. Even without looking for the deepest sense of a literary work or without wanting to find the etymology of a word, anyone would be confused when asked to clarify the nuances of a notion. (Apostolescu, 1983, p. 108)

The hermeneutics of sense, as theorized by Eugenio Coseriu, has as its subject-matter the systematic and justified revelation of the content of a text or discourse. When Apostolescu envisages "a deeper sense of a literary work" or "the sense of a line, of a poem, of a drama, of a philosophical doctrine", the meaning he gives to the term sense is very similar to Coseriu's concept of 'sense'. What might have motivated our author to establish an analogical relation between what a literary critic does when analyzing a text, for instance, and what a common speaker does when looking for the origin of a word or expression?

In order to prove Apostolescu's analogy true, I will give an example from phraseology. The set phrase a-și aprinde paie in cap [literally, 'to light straw above one's head'] designated the action of complaining, according to the Turkish custom, i.e. a certain official would be presented a certain injustice by means of wearing rug in flames above one's head. But the respective action might have had the opposite effect: "From drawing attention on a certain dissatisfaction or complaint to making someone furious because of this complaint-it is a short way" (Șăineanu, 1999, p. 234). How did this set phrase change its meaning? Definitely, not through a metaphor! Usually, the speaker evaluated a situation designated by the respective phrase and reached the conclusion (based on the knowledge of "things") that "a-și aprinde paie-n cap" in those times led to a different meaning than it was initially thought (or hoped). In other words, the common speaker grasped the sense of a (repeatable) situation, had the illumination similar to that of someone who understood a joke, or similar to that of a literary critic who understood a difficult poem. When Apostolescu refers to that "combination of semasiological and noematological phenomena", we realize that, in fact, we deal with a combination of signification with designation. This is how Coseriu explains the birth of a sense of a text. Even if only in mind (as inner discourse), that is how the sense of an interpreted situation ("linguistically" thought) is produced. 
Obviously, interpretations can have various degrees of scientificity. The speaker, in his naivety, can be wrong when wanting to explain, for instance, the origin of a word. This is how folk etymology appears. Either good or bad, the "sense grasped" ${ }^{14}$ by the speaker represents an explanation (actually, one of the meanings of the Old Greek term hermeneia was precisely that of 'explanation'). As Apostolescu remarks, the same thing can happen to the one who looks for the "deep meaning" of a literary work. Nowadays, one can say that literature is the medium in which misinterpretations (cases of "aberrant decoding", in U. Eco's terms) are most frequently encountered (see Munteanu, 2012b).

Starting from the studies or books of his favoured linguists, N.I. Apostolescu offers other examples of semantic changes through which some latent meanings, motivated by specific historical conditions, replaced the significations characteristic to some words. His justifications (resorting to John Stuart Mill's logic, for instance) may not always be the most appropriate ones. At times, he seems to mistake (what is currently named) common lexicon for specialized lexicon (or terminology), even if the intuition taken as a point of departure is not wrong in itself (also cf. Munteanu, 2011b). But the way (agreed by Hasdeu) in which Apostolescu develops and takes further the ideas learnt from his magister is really impressive. Considering all these, Apostolescu deserves all our appreciation.

\section{By way of conclusion}

In conclusion, I would draw attention to a typical example of... faulty reception of a new theory, as it is the noematological project initiated by B.P. Hasdeu and refined by Nicolae I. Apostolescu. Here are the comments, lacking in comprehension and capacity of prediction, made by one of Apostolescu's contemporaries, a certain D.M., irritated by the fact that Hasdeu's disciple had been rewarded for his merits with a "Iosif Niculescu" scholarship (in order to study in Paris):

The reason for granting scholarships is sometimes ridiculous. Thus, in 1905 a scholarship for semasiology and noematology was granted. Firstly, noematology is a term by which Hasdeu designated precisely what we, the others, understood by semasiology. Thus, semasiology and noemato$\operatorname{logy}$ mean semasiology and semasiology. Secondly, semasiology is a tiny fragment of the history of a language and has not come to being a separate subject—there are even some philologists who deny the possibility of establishing the science of semasiology. That is why there is no special chair for semasiology at any university worldwide, and no philologist considered semasiology as the subject-matter of his exclusive preoccupations. (D.M., 1910, p. 343)

It is pointless insisting on these words. And so might others from the respective epoch have thought. To N.I. Apostolescu, Hasdeu's (known for his exceptional intuition as regards values ${ }^{15}$ ) confirmative judgement must have been more important, together with his own awareness of the fact that he was working on the consolidation of a new domain. Unfortunately, his hostile destiny did not allow him to complete his work during his lifetime. But his great ideas can be rediscovered and exploited by posterity. At this point, I find it useful to reproduce some personal reflections from 2015, when I was referring (among other things) to noematology, as well:

A cultural discovery is not, however, similar to a geographical one. Even if forgotten, it can be rediscovered, (re)used and exploited. There are histories of linguistics (or of linguistic ideas) which ignore these isolated (but bright) theories that had no influence on the further development of the respective science. Similarly, there are researchers who think that their subject

\footnotetext{
${ }^{14}$ John Dewey frequently defines the process of understanding as follows: "to understand is to grasp meaning".

${ }^{15}$ In this regard, I choose to mention, at this point, only one case (of those remarked by Cicerone Poghirc in his monograph devoted to Hasdeu): “[...] I.A. Baudouin de Courtenay, whose name frequently appears [in his work], and with whom he had an exchange of letters, leading to their friendship, was «discovered» (one can say) for the European science by B.P. Hasdeu, who had foreseen him, from his very first papers, a brilliant career, which was to be later confirmed by Ferdinand de Saussure's appreciations" (Poghirc, 1968, p. 77).
} 
starts with them and do not take into account their forerunners' contributions (at least for mentioning them, even if those old results are not fully satisfactory to them). There are also excellent ideas or intuitions of some brilliant scientists which appear too early and they cannot be totally understood (yet) by their contemporaries; they need more favourable times to come. Moreover, there are well founded theories which, unfortunately, were born in the context in which the "trends" (and not necessarily the "paradigms") in science were changing, and were, consequently, considered "outdated". Why isn't a cultural discovery (completely) similar to a geographical one, even when it goes (for a while) unnoticed? Because, unlike the geographical one, it already contains some meanings, its own meanings. These can be resumed, verified and multiplied. (Munteanu, 2015, p. 68).

\section{Bibliography}

Apostolescu, N. I. (1909). L'Influence des romantiques français sur la poésie roumaine, avec une Préface de Émile Faguet, Librairie Ancienne Honoré Champion, Paris.

Apostolescu, N. I. (1983). Studii și portrete literare, edition and foreword by Ion, Editura Dacia, Cluj-Napoca.

Bianu, I. (1905). Raport general asupra lucrărilor prezentate la concursul premiilor anuale din 1904: Marele Premiu Năsturel, Eliade-Rădulescu și Adamachi, in "Analele Academiei Române”, Partea Administrativă şi Desbaterile, Seria II, Tomul XXVII, 1904-1905, Institutul de Arte Grafice „Carol Göbl” S-sor Ion St. Rasidescu, București, p. 313-327.

Bréal, M. (1868/1882). Les idées latentes du langage [lecture from 1868], in Michel Bréal, Mélanges de mythologie et de linguistique, deuxième édition, Librairie Hachette et $C^{\text {ie }}$, Paris, 1882, p. 295-322.

Dewey, J. (1963). Philosophy and Civilization, Capricorn Books, New York.

Dinu, I.M. (1983). Nicolae I. Apostolescu. Omul și opera, Editura Scrisul Românesc, Craiova.

D.M. = (1910), [review of] Victor Atanasiu, Monografia fondurilor Răducanu Simonidi și Iosif Niculescu, București, GöblRasidescu, 1909, 1 vol. în 8 mic de 277 pagini, fără preț, in "Viața romînească", V (11), p. 342-344.

Dumistrăcel, S. (2001). Pînă-n pînzele albe. Expresii românești (the $2^{\text {nd }}$ revised and augmented edition), Editura Institutul European, Iași.

Faifer, F. (2004). Apostolescu, N.I., article in [Academia Română] Dicționarul general al literaturii române (coordinated by Eugen Simion), vol. I (A-B), Editura Univers Enciclopedic, București, p. 206-207.

Gadamer, H.-G. (2001). Adevăr și metodă, translation by Gabriel Cercel and Larisa Dumitru, Gabriel Kohn, Călin Petcana, Editura Teora, București.

Hasdeu, B. P. (1988). Studii de lingvistică și filologie, vol. I and II, edition, introductory study and notes by Grigore Brâncuș, Editura Minerva, București.

Hasdeu, B.P. (2013). Studii de știința limbii, editorial note, introductory study and notes by Cristinel Munteanu, Editura Institutul European, Iași.

Husserl, E. (2011). Idei privitoare la o fenomenologie pură și la o filozofie fenomenologică. Cartea întâi: Introducere generală în fenomenologia pură, translation from German by Christian Ferencz-Flatz, Editura Humanitas, București.

Martha, C. (1907). La délicatesse dans l'art [1884], quatrième édition, Librairie Hachette et C $C^{\mathrm{ie}}$, Paris.

Moroianu, C. \& Munteanu, C. (2016). Sur la polygenèse dans la terminologie linguistique: paronymes et homonymes terminologiques, in "Revue roumaine de linguistique", LXI (2), p. 207-220.

Munteanu, C. (2007). Sinonimia frazeologică în limba română din perspectiva lingvisticii integrale, Editura „Independența Economică”, Pitești.

Munteanu, C. (2011a). Cînd Coşeriu (pare că) greșește, in "Analele Universității «Dunărea de Jos» din Galați”, fasc. XXIV, IV (2), Lexic comun / Lexic specializat, Editura Europlus, Galați, p. 26-50.

Munteanu, C. (2011b). Despre necesitatea implicării skeologiei lingvistice în socioterminologie (cu o privire specială asupra sintagmei „apă minerală”), in "Analele Universității «Dunărea de Jos» din Galați", fasc. XXIV, IV (2), Lexic comun / Lexic specializat, Editura Europlus, Galați, p. 219-230.

Munteanu, C. (2012a). Lingvistica integrală coșeriană. Teorie, aplicații şi interviuri, Editura Universităţii „Alexandru Ioan Cuza”, Iași.

Munteanu, C. (2012b). Aberrant Decoding and Its Linguistic Expression (An Attempt to Restore the Original Concept), in "Procedia - Social and Behavioral Sciences", vol. 63, p. 229-241.

Munteanu, C. (2013). Noematologia lui B. P. Hasdeu: o anticipare a skeologiei lui E. Coşeriu, in "Philologica Jassyensia”, IX (2), p. $85-94$.

Munteanu, C. (2015). Cîteva metafore privind valoarea descoperirilor și puterea tradiției în știință, in „Limba română” (Chişinău), XXV (1-2), p. 62-70. 
Munteanu, C. (2019). John Dewey și problema sensului. Premise pentru constituirea unei hermeneutici integrale, Editura Universității „Alexandru Ioan Cuza”, Iași.

Poghirc, C. (1968), B. P. Hasdeu. Lingvist și filolog, Editura Științifică, București.

Quintescu, N. (1905), Raport [privitor la N.I. Apostolescu, Studii, Bucureşti, 1904], in "Analele Academiei Române”, Partea Administrativă și Desbaterile, Seria II, Tomul XXVII, 1904-1905, Institutul de Arte Grafice „Carol Göbl” S-sor Ion St. Rasidescu, București, p. 420-423.

Rother, C. (2005). Der Ort der Bedeutung. Zur Metaphorizität des Verhältnisses von Bewußtsein und Gegenständlichkeit in der Phänomenologie Edmund Husserls, Verlag Dr. Kovac, Hamburg.

Şăineanu, L. (1999). Incercare asupra semasiologiei limbei române. Studii istorice despre tranzițiunea sensurilor [1887], edition, introductory study and indices by Livia Vasiluță, Editura de Vest, Timișoara. 